\title{
МОНГОЛЧУУДЫН ТЭМЭЭН ЖИНГИЙН СОЁЛ
}

\section{Өрнөхдэлгэр Д.}

хэл бичгийн ухааны доктор

Ховд их сургууль, дэд профессор, Ховд, Монгол Улс

E-mail: өрнөхдэлгэр@gmail.com

Товч хур а а нгуй

Энэхүү өгүүлэлд монголын нүүдэлчид тэмээгээр алс хол тээвэр хийсэн түүх, уламжлал, бусад улс орон, үндэстэнд үл давтагдах тэмээн жингийн соёл, арга ухаан, тэмээн жинд холбогдох зан үйл, үг хэллэг, нутаг нутгийн давтагдашгүй онцлогийн талаар өгүүлжээ. Монголчуудын эрт цагийн амьдралын нэгэн хэмнэл, утга учир болж ирсэн тэмээн жин нь он удаан жилийн баялаг түүх, зан үйл, өв соёлыг өөртөө шингээсэн байдаг. Монголчууд эрт дээр үеэс тэмээ унаж, нурууг нь ачиж, чарганд унадаг мал, унаа тээвэр хийдэг уламжлалтай. Саяхныг хүртэл Монголд авто тээвэр, төмөр замын хөгжил сул байсан тэмээг өргөнөөр ашиглаж ирсэн. Тэмээ нь улс орон, ард түмэнд хэрэгцээтэй бараа, ачааг тээвэрлэх, малчдын шилжилт хөдөлгөөнд өргөн хэрэглэгддэг. Одоо ч гэсэн нутгийн малчны өдөр тутмын тээвэрлэлтэнд тэмээ голчлон ашиглагдаж байна. Ази Европыг холбосон худалдааны буюу Торгоны замын гол тулгуур нь тэмээ, тэмээний цуваа байсныг түүх гэрчилнэ. Энэхүү торгоны замыг хөгжүүлэхэд Чингис хааны үеийн Монголын эзэнт гүрэн чухал үүрэг гүйцэтгэсэн бөгөөд 13-р зуунд Монголд «Тэмээ ачааны яам» гэгчийг байгуулж байжээ. Тэмээ холын замд тээвэрлэх, дайнд зэвсэг ачих, олз тээвэрлэхэд гол үүрэг гүйцэтгэсэн тул Тэмээний яамыг байгуулжээ. Их Монгол улсын үед Торгоны замын зүүн салбар Хархорум хотоор дайран өнгөрдөг байжээ. Торгоны зам нь Төв Ази, Монгол, Хятад, Энэтхэгийг Ойрхи Дорнод, дараа нь Европтой холбож, эдгээр улсын хороодын харилцаа холбоо, худалдаа, соёл иргэншил тогтооход чухал үүрэг гүйцэтгэсэн. Торгоны замын урт нь 7000 гаруй км байв. Мөн энэ замын ихэнхийг тэмээгээр туулдаг байв. Торгоны зам бий болсноос хойш Монголын нүүдэлчид тэмээ жинлэх нарийн арга бий болсон нь аль ч улс орон, үндэстэнд байдаг. Чухамдаа олон зууны турш тэмээ нь улс орон болон хөрш зэргэлдээ улсуудтай худалдаа наймаа хийх цорын ганц тээврийн хэрэгсэл байсаар ирсэн. Тэмээ Монголын аль ч аймгаас нийслэл Улиастай, Ховд, Санбээс, Хиагт, Зая шавь, Вангийн хүрээ, мөн Хятадын Бээжин, Чуулалт хаалга, Хөх хот, Манжуур, Хайлаар, Долон нуур, Цонж, ОХУ-ын Бар хул, Өрөмч, Гүнчэн, ЖанчхүҮ, Бийск, Хош-Агач, Троицкосавск хотууд ноос, арьс, үс, гурил, будаа, цай, даалимба (хөвөн) нийлүүлдэг.

T Y л х Y Y p Y г

Тэмээн жин, ёс заншил, Хан Хөхий хошууны жинчид. 
UDC 94(517)

\title{
MONGOLIAN CAMEL CARAVANS CULTURE
}

\author{
Urnukhdelger D. \\ Ph.D \\ Hovd university, Associate Professor, Khovd, Mongolia \\ E-mail: өрнөхдэлгэр@gmail.com
}

\section{An not a tion}

This article describes the history and traditions of Mongolian nomads transporting camels over long distances, the culture and methods of camel caravans that are unique to other countries and nations, the rituals, language, and unique features of camel caravans. Camel caravan, which has been one of the rhythms and meanings of the ancient life of Mongolians, has a rich history, customs and heritage for many years. Mongolians have a long tradition of riding camels, loading their backs, and riding in sleighs. Until recently, camels were widely used in Mongolia for the development of road transport and railways, as well as for the transportation of goods needed by the country and the people. Camels are still the main source of transportation for local herders. Mongolians have a long tradition of riding camels, loading their backs, and riding in sleighs as draught animal, and transportation. Until recently, camels were widely used in Mongolia for the weak development of road transport and railways. Camels widely used for the transportation of goods and goods needed by the country and the people, as well as for the movement of herders. Even today, camels are mainly used for daily transportation and transportation of local herder. History has shown that camels and camel caravan were the mainstays of the trade or Silk Road connecting Asia and Europe. The Mongol Empire during the reign of Genghis Khan played an important role in the development of this Silk Road, and in the $13^{\text {th }}$ century the so-called "Ministry of Camel of burden" was established in Mongolia. The Ministry of Camels was established because camels played a key role in carrying long distances, loading weapons in war, and transporting booty. During the Great Mongol Empire, the eastern branch of the Silk Road passed through Kharkhorum. The Silk Road connected Central Asia, Mongolia, China, and India with the Middle East and later Europe, and played an important role in establishing contacts, trade, and civilization among the committees of these countries. The length of the Silk Road was more than 7,000 km. and most of this road was traveled by camels. Since the advent of the Silk Road, Mongolian nomads have developed a sophisticated method of camel weighing that is unique to any other country or nation. In fact, for centuries, camels were the only means of transportation for trade and commerce within the country and with neighboring nations. Camels moved from any province of Mongolia to the capital, Uliastai, Khovd, Sanbees, Khiagt, Zaya Shavig, and Wang Khuree, as well as to Beijing, China, Chuulalt-Gate, Hohhot, Manchuria, Hailar, and Dolon Lake, Tsonj, Bar Khul, Urumch, Gunchen, Zhanchkhuu, Biysk, Khosh-Agach, and Troitskosavsk, Russia supplying with wool, hides, fur, flour, rice, tea, and daalimba (cotton).

\section{Ke y w o r d s}

Camel caravan, customs, caravan drivers of Khan Khokhii khoshuu. 


\section{УДИ Р Т ГА Л}

Монгол хүн тэмээг унаж эдлэхээс гадна нуруу ачих, тэрэг чарганд хөллөх зэргээр ердийн хөсөг, тээвэрт өргөн ашиглаж ирсэн уламжлалтай. Саяхан хүртэл манайд авто тээвэр, төмөр зам хөгжөөгүй байхад улс орон, ард олны хэргэцээт бараа таваар эд юмсыг тээвэрлэх өртөө, улаа залгуулах, малчдын отор нүүдэл зэрэгт тэмээг өргөн хэрэглэж байсан билээ. Одоо ч гэсэн орон нутгийн малчны өдөр тутмын уналга, ачилгад тэмээг голлон ашигласаар байна.

Манай орны тэмээн сүрэг 1953 оны байдлаар найман зуун ерэн таван мянга гурван зуун толгойд хүрч байсан бол одоо цөөрсөөр 2012 оны байдлаар гурван зуун мянган толгой болжээ (Монгол, 2020: 510). Энэ нь олон хүчин зүйлтэй холбоотой ч, тэмээг тэр бүр уналга, эдэлгээнд хэрэглэх хэрэгцээ багасаж үгүй болсонтой шууд хамаатай. Энэ хамаарал нь монголчуудын уламжлалт тэмээн жингийн зан үйл, соёлын айг судлан тэмдэглэхийн чухлыг сануулж буй хэрэг билээ.

Монгол тэмээний үүлдэр гэвэл, Галбын говийн улаан, Хананы хэцийн хүрэн, Дөхөм тунгалгийн тэмээ гэж байдаг. Монголчууд жинг тэмээн хөсгөөр тээдэг. Гурил будаа, цай тамхи, даавуу, даалимба зэрэг хэрэгцээт бараагаа Хятад, Орос зэрэг хил залгаа улс орнуудаас л бүр эрт үеэс татаж авч байсан болохоор тэмээ нь ч эдэлгээ дааж явж сурсан, тэсвэр хатуужилтай болсон, жин тээдэг хүмүүс нь ч олон жилийн туршлага хуримтлуулсан байдаг. Хэд хэдэн удаа жинд яваад ирсэн залууг нутаг хошууныхан нь хүний зэрэгт хүрлээ хэмээн хүндэтгэн үзэх хандлага ч байжээ. Олон түмнийхээ энэ их хүндэтгэл, хайрыг тээсэн хүний нэг бол Увс аймгийн Зүүнхангай сумын харьяат Ш. Гаадан абугай мөн бөгөөд түүний тэмээн жин тээж ирсэн амьдралын түүх, элжигэн халхуудын жин тээх уламжлал дээр тулгуурлан энэХүҮ өгүүллээ бичив.

\section{ХЭРЭГЛЭГДЭХ Y Y Н, АРГА}

Тэмээн жинд зайлшгүй байх зүйл нь хонх юм. Хонхыг хамгийн сүүлчийн тэмээний хүзүүнд голлон зүүнэ. Хонх зүүх тэмээ нь номхон, үргэдэггүй байна. Хонх зүүх тэмээ нь жигд алхаатай байх ёстой. Жигд зөв алхаатай тэмээний хонх жигд савлаж явдаг. Хонхыг гол төлөв хүрлээр хийнэ. Тэмээн жингийн үед хэрэглэж асан ийм нэгэн хонхыг доорх зургаас харж болох бөгөөд өдгөө Увс аймгийн Зүүнхангай сумын дунд сургуулийн сурагчдын хичээлийн завсарлагыг дохиолон жингэнэж байгаа уг хонх нь дээр нэр нэхэн дурдагдсан хүмүүний хэрэглэж байсан хонх бүлгээ.

Зэсээр амыг нь эмжсэн зэс амт, адаг хүрлээр хавчих хар хэмээх зуувандуу хэлбэртэй хавчиг хар, зэс, цагаан тугалганы хайлшаар хийсэн цас хэмээх цайвар хонх байдаг. Бүх хонхны хэлийг хатуу модоор хийнэ. Модон хэл нь хонхыг зөөлөн жигд дуутай болгоно. Ачаа ачиж дуусаад жин хөдөлмөгц сүүлийн тэмээнд хонхоо зүүнэ. Жингийн цуваа буух газар ирмэгц хонхыг тайлж авна. Ачиж, буулгаж дуусаагүй, тэмээ амарч байх үед хонх дуугарвал тэмээ яарч босон харайх, хөдөлж явдаг тул хонхыг зүүх, авах журмыг хатуу баримтална. Нэг зуун тэмээгээр жин тээх үед «Гүл шар» гэж нэрлэгдсэн гуулин хонхыг зүүдэг. Нэг удаад нэг зуун тэмээгээр тээх нь баяжихын бэлгэдэл гэж жинчид бэлэгшээдэг, замд тохиолдогсод ч тэдэнд хүндэтгэл үзүүлдэг байна. 
Тэмээн жинг даамал удирдаж явдаг бөгөөд хамгийн хашир туршлагатай хүнээр жингийн даамал тавьдаг. Тэрээр 4-6 жинчин, 40-50 тэмээг хариуцдаг. Жингийн даамал нь жинчдэд зөвлөгөө өгөх, явах, буух хугацаа, ажлын цагийн хуваарийг хариуцахаас гадна тэднийг төлөөлөн гэрээ хэлэлцээ хийх, хөлс хүч тохирох ажлыг мөн хариуцдаг байна. Тэмээн жин бол атан тэмээ, эр хүн хоёрыг шалгадаг, жинчний эр зориг хүн чанарыг сорьсон залуу хүний булчин махыг задалж бяр тэнхээ суулган бялдаржуулдаг хийморьлог ажил гэж үзэн монголчууд эрт дээр үеэс жинчний хөдөлмөрийг хүндэлж ирсэн уламжлалтай.

Монгол малчдын хуримтлуулсан олон зууны туршлагаас үзэхэд тэмээг голдуу 6 настайгаас эхлэн холын аян жинд явуулах нь тохиромжтой аж. Зарим нутагт таван наснаас аянд явуулах нь бий. Тэмээг 9-р сарын эцэс, 10-р сарын эхээр аян жинд явуулаад өвлийн саруудад бага зэрэг амраагаад хаврын сард багаар эдлэх нь зохистой гэдэг. Харин тэмээг зун, намар эрт аян жинд явуулдаггүй байна. Зуны цагт эдэлсэн тэмээний хавирга нуруу шалбарах, хом ширдэг нь бороо усанд норж илжрэх, дараа нь хатаж дардайн тэмээний биеийг холгох зэрэг муу талуудтай аж. Зунд аянд явсан тэмээний үс, ноос гүйцэд сайн ургадаггүй, тарга хүчийг муу авах явдал байдаг байна. Намар эрт эдэлбэл тэмээний тарга хүч гүйцэж чадаагүй байдгийн гадна авсан тарга хүчээ амархнаар хариулж алддаг байна. Тэмээг холын аянд явуулахдаа заавал сойх шаардлагатай байдаг. Сойлгогүйгээр аянд явуулбаас ул таваг нь урагдах, цоорох, хүч тарга нь түргэн муудах зэрэг гэмтэй аж. Холын аян жинд тэмээгээр дунджаар өдөрт 40-45 км, харин намар бол 30-35 км явах нь тохиромжтой гэж үздэг. Жингийн тэмээний хомыг зузаан байлгах, дулааны улиралд хомыг түр авч сэрүүцүүлэн амраах нь хүч нь хайлах, сойлго алдахаас сэргийлдэг байна. Тэмээн жинд 2 хүн тус бүр 15-аар хөтөлж 30 тэмээг нэг бааз болгодог байжээ.

\section{ХЭЛ ЭЛ Ц Ү У Л Э Г}

Ер нь тэмээн жинг бэлтгэн гаргах гэдэг бол тодорхой дэс дараатай нөр хөдөлмөр аж. Жинг хөдөлгөн гаргахдаa юуны өмнө жингийн тэмээг сонгон авах, уяж сойх ажлаас эхэлдэг.

1. Тэмээ сойх. Халуун намраар жинд явахад тэмээ хайлдаг учраас нэлээд хүйт оруулж байж жин хөдөлдөг байжээ. Жинд явуулах тэмээг 7-15 хоног заавал сойно.

2. Ачаа жиших. Нэг тэмээнд 200-250 кг ачаа ачна. Нэгтгэсэн шуудайтай (хоёр годон шуудай нийлүүлсэн) ноосыг давхарлаж хүлэн нэг талын тэн болгодог. Ноосоо хүлэх нь хүртэл тогтсон журамтай, тэнг баглах олс, дээс, сурыг тэнжээ гэнэ. Эхлээд тэнжээнийхээ голд саарахгүй гогцоо гаргана. Гогцоог ачааныхаа голд биш дотор талын дээд ирмэгт гарган, тэнжээгээ гогцоолдон хоёр тийш татаж, ачааны доод талын дээснээсээ зөрүүлж аван, гогцоотой талын эсрэг талаар дээш гарган, дээдэх дээснээсээ татаж уяна. Дээсээ дандаа хөмөрч аван нөгөө тийш нь дарж уявал ачааны хүлээс сулардаггүй.

3. Тэмээ хомнох. Тэмээ хомоо, хом нь ачаагаа даадаг гэдэг ахмадуудын үг бий. Тэгэхээр тэмээг зөв хомнох нь жин тээх ажлын чухал нэг хэсэг ажээ. Хом нь хос ширдэг, бамбай, шат, хойт урд ташаа, дуудай, өөг зэргээс бүрдэнэ.

4. Жинд явах. Жин тээх эхний хоногуудад өдөрт хол явдаггүй, өглөө нар дээр хөөргөж хөдлөөд нар жаргах юмуу, шар гэгээ тасрах үед бууж хоноглоно. Тэмээ ачаандаа дасч ирэнгүүт (4-5 хоногоос) аажмаар өдөрт явах газрын хэмжээг уртасгана. 
Өглөө зэхийхэн ачаалан хөдлөөд шөнө марал мичид нэлээд гудайлгаад (шөнө дунд өнгөрөөгөөд гэсэн үг) бууна. Цаашаа явж байхдаа ихэвчлэн арагшаа гударган газар бууж, тэмээгээ цаашаа бэлчээж хононо. Тэгэхгүй бол шөнө тэмээ нутаг руугаа цувчихдаг. Нэг майхан жинчдийг «гал» гэж нэрлэнэ. Нэг галд 3-4 хүн, зарим нутагт 4-6 хүн явна. Ханиндаа яваа хоёр галыг бааз гэнэ.

5. Тэмээ улдах. Тэмээ улдах эмгэг жинчдэд олонтаа тохиолддог. Үдэш усалбал тэмээ амархан улддаг гэнэ.

6. Жинчний арга. Жин тээх ажлын онцлогтой уялдсан янз бүрийн өвөрмөц арга ухаан олон байдаг байжээ. Жинчин хүн ганцаар ачааг ачих тохиолдолд хүн мод тээвэрлэдэг. Хүн мод гэдэг нь тэмээний буруу талын тэнг өргөж тавьдаг мод юм. Хүн мод нь ачаа ачих хоёр дахь хүнийг төлөөлдөг бөгөөд энэ нь нэг метр орчим өндөр, нэг үзүүртээ хоёр ацтай мод, энэ ацаар нь газар тулна. Уг модны ац нь 50 см орчим алцгар зайтай байна. Жинчин хүн, хүн модоо ацаар нь газар хатгаж, дээд шулуун үзүүр дэх хос оосроор нь шатны хойд урд үзүүрээс уяад ачаагаа дээр нь тавихад хөдөлдөггүй тулгуур болж өгдөг өөрөөр хэлбэл жинчин хүн буруу талын ачаа тэнг өргөж тэмээний нуруунд «хүн модоор» түшүүлэн газар тулна. Тэгээд нөгөө талд нь гарч тэнгээ өргөж холбоно. Дараа нь «хүн модоо» авч тэнгээ тэгшлэн татдаг аж.

Говийн тэмээ мөсөн дээгүүр явж чаддаггүй учир шороо зөөж асгадаг. Өндөр даваанаас зарим тэмээ сүрдээд явдаггүй. Тэгэхээр нүдийг нь бооход ямар ч өндөр давааг давдаг. Зарим аргатай тэмээ хэвтэн тусаад байхаар бодын хүзүүний ясыг нугасны нь нүхээр татлагандаа оруулан хэнхэрцэг дор нь тааруулахад нэг хоёр хэвтээд дахин хэвтэн тусахаа больдог.

Халхын аянчид ердийн хөсгөөр аялахдаа өдөр бүр үдээс хойш ачаалж бараг шөнийн турш явж, үүр цайхын өмнө бууж хоноглох, хөсөг тээврийн малыг амраах, идээшлүүлэх ажлыг нарийн зохицуулан шуурхайлж явдаг байжээ. Үүнээс улбаалан дээр өгүүлсэн «халх аялал» (халхдах) «идэр халх» хэмээх нэр гарчээ.

Монголчууд тэмээн жин тээхэд эртнээс сайн бэлтгэдэг ба юуны өмнө тэмээний уяа сойлгыг тохируулахаас гадна аяны хэрэгсэл хом, шат, тэрэг, тоног хүлэг, татлага, орон сууц (майхан) усны сав, тогоо, онгоц, ховоо, тэмээ уллах, ханах хутга шөвөг, цаг улирал аян жингийн олон цөөн хоногт тохирсон хүрэлцэхүйц хоол хүнс, хувцас хунар бэлтгэдэг байжээ. Мөн тэмээний нуруу ачих, тэрэгний ачааны хүнд хөнгөн, хэмжээ зэргийг тэмээний биеийн байдал, чадал тэнхээ, тарга хүч, нас хүйсэд зохицуулдаг байна. Мөн аялах замын ус бэлчээр, өвс ургамал, түлшний байдал, зам газрын хатуу зөөлөн, бартаа, өдөр бүрийн буудал хоорондын хол ойрын зай хэмжээг нарийн тохируулж, тэмээн жингийн өдөр, шөнийн явах хоног, тэмээг идээшлүүлэх, услах, амраaх, ул тавгийг шалгах, хайрлах зэрэгт ихээхэн анхаардаг аж. Бас тэмээн жинг хөтлөхдөө явцын ширүүн зөөлнийг тохируулах, цувуулах, зэрэгцүүлэх, тэмээний хомыг байнга засах, тэн ачих зэрэг аяны горим журмыг нарийвчлан гүйцэтгэдэг ба мөн ачааны хүнд хөнгөнийг тэнцүүлэн баглах, ачааны хүлэг сулрах ахул чангалах, жиших, өргөх, шордох зэргийг нарийн нягт нямбай тохируулах шаардлагатай бөгөөд энд жингийн даамлын хяналт, зөвлөгөө чухал үүрэгтэй аж.

Монголчууд «XVШ зуунаас хойш Хөх хот, Долон нуур, Цонж, Бархөл хотод жин тээж гурил будаа, хувин сав, бөс даавуу зэрэг бараа таваар тээвэрлэн авчирдаг болжээ. Зарим баримтаар үзвэл сайн атан тэмээ нэгэн жилийн хүч таргаар 3000 орчим км хол аян жингийн үүрэг гүйцэтгэж явсан байна. Малчид зүтгэх хүчний 
малын уяа сойлго тохируулж тарга тэвээргийг гамнах, өл хоолыг тааруулах, ачаа тээшийн хэмжээ тохируулахыг сайн мэдэж зохицуулдаг байжээ» (Бүгд Найрамдах, 1966-1969) хэмээн БНМАУ-ын түүхэнд тэмдэглэжээ. Үүнээс үзэхэд жин тээх ажил их эртний уламжлалтай ажээ.

XIX зууны үед Хятад, Оросын худалдаачдын бараа үнэ ихтэй, ховор хомс тул хүмүүс тэмээн жин хөдөлгөн өөрсдөө холоос авч ирвэл арай хямд байдаг. Иймд тус хошууны захиргаa, ард иргэд тэмээ мал, ачлагын хэрэгсэл, хом, шат, бамбай, сур, дээсээ нийлүүлж хоршин, хэрэгцээт гурил будаа, цай, тамхи, даавуу, даалимбуу зэргийг гадна дотноос тэмээн жин гаргаж, татаж авч ирдэг байжээ. Энэ нь аж төрж, амь зуухад өөрт болоод бусдадаа тус нэмэртэй ажил байжээ. Ер нь тэмээн жин олон зууны турш улс орныхоо дотоодод ч, айл хөрш гүрнүүдтэй харилцах, арилжаа, наймаа хийх цорын ганц тээвэр байсан билээ.

Ази, Европыг холбосон худалдааны буюу торгон замын ажлын гол зүтгэгч хүч нь тэмээ, тэмээн жин байсныг түүх гэрчилдэг билээ. Энэхүү торгон замыг хөгжүүлэхэд Чингисийн үеийн Монголын эзэнт гүрэн чухал үүрэг гүйцэтгэсэн бөгөөд XIII зууны үед Монголд «Ачлагын Тэмээний Яам» гэгчийг байгуулж байжээ. Алс хол аян жин тээх, дайн байлдаанд зэр зэвсэг ачих, олзны эд агуурс тээвэрлэх зэрэгт тэмээ гол үүрэгтэй байснаас ийнхүү тэмээний яам байгуулж байсан байна. Их Монгол улсын үед торгон замын зүүн салаа нь Хархорумаар дамжин өнгөрдөг байжээ. Торгон зам нь Төв Азийн улс гүрэн, Монгол, Хятад, Энэтхэгийг Ойрх Дорнодын болон улмаар Европын улсуудтай холбож, эдгээр улс орнуудын хооронд харилцаа холбоо тогтоох, худалдаа арилжаа хөгжүүлэх, соёл иргэншил дэлгэрүүлэхэд чухал үүрэг гүйцэтгэж байв. Торгон замын урт нь 7000 гаруй км байсан гэх бөгөөд энэ замын ихэнхийг тэмээгээр туулдаг байжээ (Төмөржав, 2004: 238-239).

Торгон зам үүсэн бий болсон тэр үеэс эхлэн монголын нүүдэлчид тэмээгээр алс хол тээвэр хийх, өөр аль улс орон, үндэстэнд үл давтагдах тэмээн жингийн нарийн арга ухааныг бий болгожээ. Гэвч монголчуудын тэмээн жингийн талаарх нарийн ур ухааныг бичиг сударт тэмдэглэж үлдээсэн нь бага аж. Гэхдээ Т. Аюурзана (1947), Ш. Цэрэнпунцаг (1972), Б. Лувсан (1975), Ц. Насанбалжир (1978), Ю. Адъяа (1979), М. Төмөржав (1989), Д. Цэвээнжав (1990), Н. Банди (1991), Н. Эрдэнэцогт (1998), С. Жамбалдорж (1997), Ш. Эгшиг (2017) нарын бүтээлд тэмээний бие махбодын биологийн онцлог, ажил эдэлгээний чадвар, ердийн хөсөгт, аян жинд тэмээг ашиглаж ирсэн уламжлалын талаар дурдсан байдаг.

Б. Цэвээн «Жинчин» гэдэг тууждаа алс холын аян жинд идэр залуугийн бяр чадал, золбоо хийморио бадруулж яваа жинчин эрийн амьдралыг урнаар өгүүлсэн байдаг. Бас Монгол орон даяар ардын дуу мэт дэлгэрсэн алдарт дуучин М. Дугаржавын зохиосон «Идэр жинчин» дуунд монгол атан тэмээний бяр чадал, монгол жинчин залуусын эрэмгий зориг, авхаалж самбаа зон олноо гэсэн тэдний эрхэм буянтай үйлсийг магтан өгүүлжээ. Зохиолч П. Лувсанцэрэн «Ус шиг цэнхэр» өгүүллэгт жин тээж хол яваа хайртай залуудаа ус шиг цэнхэр торго захидгаас ховор нандин эд зүйлийг жинчид олж ирдгийг, Төрийн хошой шагналт зохиолч Д. Намдаг «Цаг төрийн үймээн» романы нэг шугам Бээжин лүү жин тээж буй бүлэг хүмүүсийн тухай, тэдэнд тохиолдсон хэрэг явдлыг уран нарийн дүрсэлсэн байдаг.

Зохиолч Д. Оюунчимэгийн «Оройн ганц мод» (2016) романд «Алтайн Урианхайн баруун гарын Дархан бэйсийн хошууны бүлэг жинчид Өрөмч ороод буцаж явах ажээ. 
Далан тэмээ хөтөлсөн эл нүсэр жингийн даамал Борх ах бол жин тээх үйлийн нарийн ширийн эрдмийг (тэмээн ачаа хөтлөх, тэмээдийн уяа сойлго тааруулах, ачаа тэнцүүлэх, хуваарилах, буух, үдлэх газраа сонгох гэх мэт) гаргууд эзэмшсэн, байгалийн хатуу сорилгыг даван туулж сурсан, чухам жингийн даамал хэмээх албандаа бүрэн зохирсон дүр тэргүүтнийг гаргасны дээр жин тээж яваа хүн нэг бүрийн зан ааш, хэл яриаг тод томруун дүрсэлсэн» урианхай түмний ахуй соёлын нэгээхэн хэсгийг жин тээх үйлээр нээн харуулсан байна.

Үүнчлэн, «Жин хөвөрч жингэр боргоож л байг», «Тэмээ хариулсан хүн буурныхаа занг андахгүй» зэрэг утга соёлын улбааг тээсэн сонин содон үг хэллэгүүд олон арвин бий. Нэг жишээ сонирхуулахад, «Бөх хөл, холбоо бөх, ховилтсон нуруу, хөвч нуруу, суунги борви, босоо борви, тэнчээ, ачаа жиших, хөм, хог, ширдэг бамбай, шат дуудай, өөг, ойлуур, ороолт, халх явдалт, харчин явдалт, гал, баз, майхны хэц, майхны сүүл, майхны гэдэс, алтан хумс, уг хугарах, ул цоорох, тэмээний ул тахлах, зогдор татах, ул ширлэх, хүн мод зэрэг» (Банди, 1993) тэмээн жин тээврийн дөчөөд нэр байна. Тэмээний хомын тухайт гучаад нэр томьёо байна. Тэмээний явдлыг гэхэд алхах, зогдор хөдөлгөх, бөх хөдөлгөх, жонжих, тэших, таваргах гэсэн зургаан зүйл үгээр, илэрхийлжээ.

Монголын аль ч аймаг хошуунаас тэмээн жин хөдөлгөн тэр үеийн арилжаа наймааны төв газар Нийслэл хүрээ, Улиастай, Ховд мөн Санбээс, Хиагт, Заяын шавь, Вангийн хүрээ рүү, түүгээр ч барахгүй Хятадын Бээжин, Чуулалт хаалга, Хөх хот, Манжуур, Хайлаар, Долон нуур, Цонж, Бар хөл, Өрөмч, Гүнчен, ЖанчхүҮ, Оросын Бийск, Хош-Агач, Тройцкосавск зэрэг хот руу ноос, арьс шир, ангийн үс тээж, гурил, будаа, цай, даалимба хүн амын өргөн хэрэглээний бараа ачиж ирдэг байжээ.

Ц. Насанбаржир (1978) ХХ зуун гэхэд Говь, тал хээрийн бүсэд нутаглах Халхын 70 шахам хошууд тэмээн хөсөг хөдөлгөдөг байсныг дурдаж, сайн атан тэмээн нэг жилийн хүч таргаар 3000 орчим км хол аян жингийн үүрэг гүйцэтгэж явсан гэж өгүүлсэн байдаг.

С. Жамбалдоржийн (1997) тодорхойлсноор, тэмээн жин хоногт 10-16 цаг, цагт 3-4 км-ын хурдтай явдаг бөгөөд жингийн цуваанд 20-30-аaс 200-1000 хүртэл атан тэмээ, 200 гаруй жинчин оролцдог ба аян жингийн нэг удаагийн замын урт 20 өртөө (600 км) хүртэл байвал ойрын, 50 өртөө (1500 км) бол холын, үүнээс дээш бол алсын аян жин гэдэг байна. Монголчууд 2000 гаруй км хүртэл алсын замд жин тээдэг байжээ. Жинд 7- 17 насны атан тэмээг хэрэглэдэг. Жил бүрийн 11-р сарын нэгнээс дараа жилийн 4 сар хүртэл аян жинд явдаг байжээ.

Ц. Насанбалжирын бичсэнээр ХХ зууны эхээр зөвхөн Их Хүрээн дэх Хятадын худалдааны пүүс жил тутамд Монголоос 160000-200000 пүү ноосыг Хятадад гаргахад 10 гаруй мянган тэмээн хөсөг хөдөлгөж байсан байна. XX зууны эхэн үеэр Монголын гадаад дотоодын тээвэрт барагцаалбал жил тутам 350-400 мянган хөсөг хөдөлгөж үүний дийлэнхийг тэмээгээр гүйцэтгэж олон арван мянган хүн тээвэрлэх ажил хамрагдаж аянч, жсин гэдэг нэгэн ажил дагнасан хүн олон байх болжээ. Монголд мал аж аж ахуйн туслах салбарын дотроос жин тээврийн ажил нь хамгийн илүү ашиг орлоготой, олныг хамарсан шинжтэй байсан байна.

Тэмээн жинг дотор нь халх аялал (халхдах), харчин аялал (харчиндах) гэж хоёр хэлбэрт ялган үздэг тухай С. Жамбалдорж өөрийн бүтээлдээ дурджээ. Халх аялал нь нар гарахын өмнө ачаалж өдөржин яваад орой харанхуй болмогц буудаг аялал 
бөгөөд өөрөөр хэлбэл өвлийн өглөө 5-6 цагийн хооронд хөдөлж, 11-13 цаг яваад орой 16-18 цагийн үед буудаг байна. Харчин аялал нь өвлийн өдөр үдээс хойш буюу үдэд шахам ачаалж, шөнөжин яваад үүрээс өмнө тэмээ унтахаас наана буудаг аялал ажээ. Өөрөөр хэлбэл үдээс хойш 15-17 цагийн турш яваад шөнө 2-3 цагийн хооронд буудалладаг байна. Жинчид өвөл, намарт үдлэлгүй харчиндахыг тохиромжтой гэж үздэг. Халх аялал, харчин аялал хоёр нь дотроо идэр халх, хөгшин халх, хөх харчин, үдтэй харчин гэх мэт хувилбартай байдаг аж. Тэмээ тарган, жинчин нь залуу, зам богино, бартаа бага бол «идэр халх» аргыг хэрэглэдэг. Энэ нь өдөр бүр аажим ачаалж, өдөр дундаас хойш үдлэн тэмээ хүнээ амрааж хооллуудаад орой нар шингэхийн өмнөхөн ачаалан явж үүр цайхын өмнө бууж хоноглодог. Өөрөөр хэлбэл цаг орчим үдлээд орой 18 цагийн үед хөдөлж, шөнийн 4 цагийн орчимд бууж хоноглодог байна. Хөх харчин, үдтэй харчин гэдэг нь орон нутгийн чанартай ойлгоц аж. Ер нь бүс нутгийн тухайлбал, ойт хээр, тал хээр, говь нутгийн онцлогоос болон жинчдийн арга ажиллагаа, тогтсон дадал барилаас болж бүс нутагт тэмээн жин тээх нь бас өөрийн онцлогуудтай байсан байна.

Тухайлбал, Засагт хан аймгийн Хан Хөхий уулын хошууныхан «1881 онд Цонж руу жин тээхээр Аюуш, Цогбат, гэлэн Түмэн, Өнөржаргал, Санжжав, Самбуу, Пунцаг, Дунгаа нар явж байсан бол, 1891 онд хаван Цэвэгжав, дагалдан Тайван, гэрийн дарга Тайвангийн аравны Энхмэнд, заан Цогт-Очир, зайсан Борхул, Гэндэй, Мөнхжав, Балжинжав, Санжаа, Хишигдэлгэр, өвгөн Чиваахай, 1908 онд Дориг, Самбуу, Ламжав нар мөн Гучен хот руу жин тээж гурил будаа авахаар арьс шир, бараа зэрэг юм авч, 80 хоногийн хугацаагаар зам явах тэмдэгт бичиг авч явж байжээ» (Түмэнжаргал, Мэндсайхан, 2017: 159-163). Ингэж хошууны өмнөөс, мөн хувиасаа тэмээгээр явж, Бар хөл, Хөх хот, Хөшөө мод, Цонж. Да хүрээ, Ховд, Улиастай, Хатгал, Хиагт зэрэг газраас гурил будаа, бөс бараа, чихэр бурам, гэр ахуйн бараа авч ирдэг байв.

Арван гэрээрээ нийлж, тус бүр нэг хоёр тэмээ гаргаж, жинд явах явдал байжээ. Хүмүүс ингэж хувиараа жин тээхэд, үлдсэн аав, ах нараар нь жинд яваад өр төлбөрт орвол би төлнө гэсэн батлах бичиг гаргуулж авч явуулдаг байжээ.

1895 оны намар Занаа хэмээх хүн Их хүрээ рүү жин тээхээр явахдаа Сүрэнгээс 16, Санлин дацангаас 7, Дэмчиг дацангаас 5, хуруу Лхамсүрэнгээс 4, нярав Вандангаас 2, зайсан Борхулаас 1, адууч Эрдэнэцогтоос 1, бүгд 36 атан тэмээ авч явж байжээ.

1897 оны хавар нярав Вандан Их хүрээнд жин тээхээр явахдаа хошуу ноёны сан сүргээс 22, дарга Баян, Намсүм-Очир, баян Донжав, Дугуйцагаан, Мэнд, Балган, гэлэн Хөтөл, агтач Чүлтэм, тайж Жамба, Баттогтох нараас 28, бүгд 50 атан тэмээтэй очихдоо 43 атан тэмээгээр 860 зузаан цай, 100 ширхэг хурганы арьс, 60 ширхэг нэхий ачиж аваачаад, ирэхдээ бөс бараа, зэс, цагаан тугалга, гөлөм, 6 ба 7 тамгат тогоо, жалавч тогоо, гуулин халбага, хүрз, балт, туужуур, хавтага, хэт, бэлний оосор, орос цаас, хүж, булигаар, сайр, сарьс, гутал, хамрын тамхи, архи, чавга, бурам, дүнс, олон төрлийн цай ачиж авч ирж байжээ.

Жинд явахдаа эмгэг хуучгүй, эрүүл, номхон, нас бие гүйцсэн тэмээнүүдийг айлуудаас хөлсөлж авдаг. Хөлсөлж авсан тэмээнүүдээ 3-4 хоног уяж сойж байгаад явна. Нэг хүн 10 тэмээтэй, 3 хүн 30 тэмээтэй 1 гал болж явна. Хом шат, хасуу, бамбай зэргээ сайн бэлтгэнэ. Явахдаа арьс шир, ноос үс зэрэг түүхий эд, ирэхдээ гурил 
будаа, бусад бараа таваар ачиж ирнэ. Морь унаа хэрэглэхгүй, унаарын тэмээ авч явна. Жин тээх явдал бүр 1950-1960 аад он хүртэл үргэлжилсэн. Тэмээний хөлсөнд гурил будаа өгнө.

Цагаан нуурт 25 хоног, Хатгал, Бийскт 40-өөд хоног явж ирнэ. Зарим тэмээ Цагаан нуурт жилд хоёр явна. Ширээ сайхан ат жинд яваад хоёр ташаа нь цоорсон, таваг нь урагдсан, бөх нь шалчийсан юм болж ирнэ. Жинчид ачаагаа баглаж, нэгэнд нь гогцоо гаргаж, нөгөөд нь чагт гаргана. Тэгнэж ачих нэг ачаагаа тэмээнийхээ нуруун дээр тавьж байгаад, нөгөөг өргөж гогцоонд оруулж чагтлаад буулгаж тэгшлэх зэргээр ганцаараа ачих явдал олонтоо тохиолддог байв. Тэмээний ханзарсан тавгийг оёх, тостой хөө түрхэх зэргээр эмчилж анагаадаг байсан.

Сарын саруулд шөнө явна. Хамгийн сүүлийн тэмээнээс хонх зүүдэг. Өдөр нь тэмээгээ идүүлнэ. Зарим өвс ихтэй газар өнжиж хонож тэмээгээ амраана. Тэмээнд 70 кг-ийн хоёр уут гурил ачна, гурван уут гурил ачвал нүднээс гарч ирнэ. Зарим омголон тэмээнд омгийг нь дарах гэж гурван уут гурил ачиж нүднээс гарган өвчин эмгэг олгож үхүүлэх явдал гарна. Хашир туршлагатай жинчид ингэхгүй, тэмээгээ өвс усыг нь тааруулж гамтай эдэлж турааж эцээх нь бага байдаг.

Мөн түүнчлэн хошууны ноёд түшмэд, чинээлэг баян хүмүүс, панзач наймаач нар үе үе Ховд, Улиастай, Да хүрээнд адуу мал тууж, аваачиж зарах явдал байжээ. Лу жанжин гүн 1905 онд Богдын хүрээ орох, Далай ламтай уулзах гэж явахдаа ноёныхоо сан сүргээс 37 морь, их жас, санлин, майдар, мамба, чойр дацангаас 14 морь нийт 51 морь авч явж 1192 лан, 4 цэн, 8 пун мөнгөөр худалдаж байжээ.

Орос, Хятад зэрэг хол газар аян тээхэд хань ижилтэй, буу саадагтай мэдэлтэйхэн явахгүй бол дээрэм тонуул таарч амь насаараа ч хохирно. 1930-аад онд Лааган заан Бяруу заан хэмээх ах дүү хоёр бөх Бийскт жин тээгээд ирж яваад Урианхай нарт дээрэмдүүлж хоёул алагдаж байсан түүх байдаг. Бүр дээр үед Тэнгэрийг тэтгэсний 47 (1763) онд Долон нуурын газар аялан явсан Бямба нарын 4 хүнийг замаас нь Цэцэн хан аймгийн Даадангийн хошууны занги Цүлтэм гэдэг этгээд алж, ачиж явсан тэмээ эд юмыг дээрэмдсэн тухай архивын баримт байдаг. Цонж, Бийск зэрэг газар явж жин тээсэн хүмүүс Хасаг, Уйгарын дээрэмч, тонуулчдаас их айж болгоомжилдог байжээ. Жин тээнэ гэдэг нь ийм л их эрсдэлтэй ажил байжээ.

Аян жинд явахдаа 10 гаруй хоног тэмээгээ сойж, хоол ундаа бэлтгэнэ. Борц хийхгүй, 20-оод тэмээтэй хоёр хүн нийлж нэг хонь алж боов боорцог хийгээд авч явна. Жинд явахдаа шинийн сар гарахаар л явна. Жин дан намар ноос ачаад манай эндээс зүүн тийш Хатгал, баруун тийш Цагаан нуур ордог. Өөр тийш явахгүй. Жингээ дагаад голцуу тэмээ унаад явна. Хатгал руу сар, Цагаан нуур руу 45 хоног яваад ирнэ. Аянд явахын тулд урьд өдөр 2-3 тэмээнд хомоо ачаад ойрхон явж “мөрөө" гаргана. Сайн өдрөө явж чадахгүй байж магад гэж тэгж байдаг байсан. Монгол майхан, ганц тогоо, аяга, тулгатай явдаг. Хүн бүр нэг нэг гудастай дээлтэй явна. Буухдаа ачаагаа бүгдийг буулгаад хомыг авч жаахан сойж уяж байгаад идүүлнэ. Аянчид гурилтай хоол, бүхэл мах иднэ. Хар цай ууна. Аяны үед бурантаг, олсоо их гамнаж хайрлаж явдаг. Хээрийн хүн тогоо сав, юмаа их цэвэр авч явна. Бохир бол тэмээ малд муу саадтай гэдэг байсан. Дээлээ тайлаад бүсээ дэрнийхээ хажууд тавиад унтана, дэрлэхгүй. Жингийн үед хүн ус аваад явж байвал тэр уснаас нь бууж амсдаг. Ер нь айл урдаас цай өгвөл их бэлэгшээдэг. Жингийн үед айл цай авчирч өгдөггүй, харин очиж л 
цай ууна. Жингийн үед багачууд залуус дуу дуулж л явдаг, ийм тийм хорио цээр үгүй, ямар ч хамаагүй дуу дуулна. Би ан хийж яваагүй”’1 хэмээн угсаатны зүйн судалгааны эрдэмтдэд ярьж тэмдэглүүлсэн байдаг (Монголын, 2011).

\section{Y $\mathbf{P}$ Д Y H}

Жин тээх ажил тэмээн жинг тээврийн машин орлох болтол өөрөөр хэлбэл 1960-аад оны эх хүртэл үргэлжилсэн. XX зууны эхэн дунд үед Цагаанхайрханы Д. Рэнцэн, Баярмагнай, С. Пүрэв, Содном, М. Очирхүү, Д. Чимэд, Д. Халзанбаньд, О. Жүгдэр, Өндөрхангайн Т. Туваан, Б. Дэмчигжав, Ху. Санжжав, Зүүнхангайн Муна, Олонхүу, Гозгор нарын алдарт жинчид байсны дотор Цагаанхайрханы алдарт жинчин Д. Рэнцэн 22 жилд нийт 53 удаа жин тээхдээ жилд ихэвчлэн 2, зарим жилд 3 удаа явдаг. Хатгалд 19, Цагааннуурт 27, Улаангомд 7 удаа аялан явахдаа эхнэр Дэжмаагаа 2-3 удаа дагуулан явж байжээ. 1960-аад онд зохиолч М. Бизъяа түүний тухай «Дэлхийн тэнхлэгийг тэмээгээр тойрсон хүн» тэмдэглэл найруулал бичиж байжээ. Д. Рэнцэн аймгийн аварга жинчин, тууварчин хүн юм.

Мөн Цагаанхайрхан сумын харьяат байгаад Өндөрхангайд Өрнөлт нэгдлийн хамт шилжсэн «Хар нүдэн» хочтой Т. Туваан гэдэг хүн 10 гаруй настайгаасаа ах «Шүр Ламбаа» хэмээх Ламжавтайгаа Шинжаан Уйгарын Цонж хот, Оросын Бийск, Цагаан нуур, Хатгал, Хатгалын дамжлага баазаар жин тээх, мал туух ажлыг олон удаа хийж байжээ. Өндөрхангайн дээр дурдсан цоохор Дэмчигжав, Хуувуузын Санжжав нар тус бүр 30 шахам жил Хөх хот, Цонж, Бийск зэрэг газар жилд 1-2 удаа явж жин тээдэг байжээ. Жин тээнэ гэдэг нь ардуудаас тэмээ хөлсөлж, хөлсөнд нь гурил будаа, цай, тамхи өгдөг, өөртөө ажлын байр амьдралын эх үүсвэр бий болгодгоос гадна ард олондоо хүнс тэжээл бараа таваар залгуулдаг, арьс хөрс, түүхий эдийг нь борлуулж өгдөг буянтай үйлстэн ажээ.

1940-1950 оны Жинчин Цагаанхайрхан сумын Ж. Дүгэрийн тухай түүний хүҮ Д.Цэрэндорж (хуучин нэр нь СССР) «Сахиус» хэмээх ургийн номондоо тэмдэглэхдээ: «Цахиуртайн хийдийн гэсгүй лам асан Цагаанхайрхан сумын харьяат Жамьшийн Дүгэр 1940-1948, 1952-1956 онд жилд нэгээс хоёр удаа жинд явж, сумын захиргааны өмнө үүрэг хүлээдэг байв. Анхны хэдэн жилдээ жинчнээр, 1940 оны сүүлчээс жингийн даамлаар явдаг болсон. Аав минь 12 жил жинд явахдаа 7 жилд нь жинчнээр, 5 жилд нь жингийн даамлаар явж жин тээсэн. 21 настайгаасаа жинчнээр явж эхэлсэн байдаг. Манай Хан Хөхий хошуунд авто тээвэр бараг байгаагүй, 1950-иад оны дунд үе хүрч байж тэмээгээр жинд явахаа больж, тээврийн машин үйлчлэх болсон. Олон сайн нэртэй жинчид байсан. Д.Рэнцэн, Г.Рэнцэн, М.Очирхүу, Т.Туваан, Өвгөдөө, Ерэнтэй, Луузан (долоон хүзүү) Гонгор, Гаадан гуай нарыг нутгийн хөгшчүүл зах зухаас нь мэддэг юм. Буурал аав энэ хүмүүсийн заримтай жинд явдаг байсан» (Түмэнжаргал, Мэндсайхан, 2017: 159-163) гэдэг.

Баян-Өлгий аймгийн Цагааннуур, Хөвсгөл аймгийн Хатгал, Ханхын дамжлага баазуудад сумаасаа шахаж боосон ноос, түүхий эд, ангийн үс арьс, бугын эвэр ачиж хүргэн өгч хариуд нь голдуу гурил, шар цагаан будаа, цай тамхи, даалимба даавуу өдөр тутмын хэрэглээний бараа таваар ачиж ирнэ.

${ }^{1}$ Увс аймгийн Зүүнхангай сумын Жаргалант бригад, Шадлангийн Муна (нас 76, эр, халх, 1972 он), Тэгшийн Буян (нас 70, эм, халх). 
«Аав намар, өвлийн эхэн сард голдуу жинд явдаг байлаа. Айл бүрээс нэгээс хоёр атан тэмээг хом бамбай шаттай цуглуулж уяа сойлгонд оруулж явах хүний тооноос хамаарч 2-3 хүн 20-оос дээш тэмээтэй жинд явна. Жингээс ирээд тэмээ авсан айлдаа хөлс болгож хэдэн килограмм гурил, будаа цай, тамхийг хуваарийн дагуу өгнө. Бараа таваар ховор байсан учир хүрэлцээг бодолцон дүнсэн тамхи, дугуй булантай цайг хувааж өгөх явдал гардаг байсан» ${ }^{1}$ хэмээн Гаадангийн том хүY Хоодон бидэнд хуучилж үлдээжээ.

\section{Д Ү Г НЭЛ Т}

Монголчууд айлын шинэ гэрийн найрт очихдоо тэмээн утас ээрч авч очдог заншилтай. Хүний толгой доргивол тэмээн утсаар боож домндог. Учир нь тэмээний толгой амар доргидоггүй байна. Тэмээний ачааг чивчиртэл нь чангалан татахыг цээрлэнэ. Эс тэгвээс аян жинд яваа тэмээний бөөр унаж гэмтэнэ гэдэг. Аян жинд малын хааны махаар хүнс хийхийг цээрлэдэг. Жин тээж яваа хүнтэй тааралдвал,

Буйлаа хугалалгүй

Бурантгаа сунгалгүй

Ачаа хүнд

Аян зөөлөн болог хэмээн ерөөдөг.

Өнөө үед алсын аян жин тээх ажил түүхийн харгуйд үлдсэн ч монгол түмний маань амьдралын нэг чухал хэсэг байсан аян жингийн тухай улам бүр сурвалжлан судалж, монгол малчны энэ өвөрмөц ажлын арга барил ур ухааны үндсийг одоогийн залуу малчдад ойлгуулах, өвлүүлэх нь эрхэм юм. Мөн, орчин үед аялал жуулчлалын эвент болгох нь туйлын чухал юм.

\section{Ном 3 Y й}

Банди Ч. Та минь, жингээ хөдөлгөх изаг боллоо. Үнэн, 1993 он, № 97.

Бүгд Найрамдах Монгол Ард Улсын түYх [ ]. Ред Б. Ширэндэв, Ш. Нацагдорж. Улаанбаатар: Улсын Хэвлэлийн Хэрэг Эрхлэх Хороо, 1966-1969.

Жамбалдорж С. Тэмээ тэнгэрийн амьтан. Улаанбаатар, 1997.

Монгол нүҮдэлчдийн тайлбар толь I (гэр, хувцас, мал аж ахуй). Улаанбаатар: Монсудар хэвлэлийн газар, 2020.

Монгольн угсаатны зүйн хээрийн судалгааны эх хэрэглэгдэхүүн. Боть VI. Эрхэлсэн С. Чулуун; Хянан нягталж, оршил бичсэн Г. Цэрэнханд, У. Булаг. Улаанбаатар, Соёмбо Принтинг, 2011.

Төмөржав М. Бэлчээрийн монгол мал. Улаанбаатар, 1989.

Төмөржав М. Монгольлн бэлчээрийн мал аж ахуй (Уламжлал, Шинэчлэл, Эрчимжүүлэлт). Ред. Ж. Батаа. Улаанбаатар, 2004.

Түмэнжаргал Д., Мэндсайхан Т. Элжсиээ халхын түYх (гуравдугаар дэвтэр). Улаанбаатар, 2017. 159-163-р тал.

Цэрэнпунцаг Ш. Тэмээн сүрэг. Улаанбаатар, 1972.

Цэвээнжав Д. БНМАУ-ьлн тэмээний аж ахуйн үндэс. Улаанбаатар, 1990.

Эрдэнэцогт Н. Монголын бэлчээрийн мал аж ахуй. Улаанбаатар, 1998.

${ }^{1}$ Гаадангийн Хоодон, эрэгтэй, нас 60. Увс аймгийн Зүүнхангай сумын Худалдаа бэлтгэл ангийн агент. 


\section{References}

Bandi Ch. Ta min, jingee khöölgökh tsag bolloo [It's time for you to move your caravan]. Unen [Truth], 1993 on, № 97.

Bügd Nairamdakh Mongol Ard Ulsyn tü̈̈kh [History of the People's Republic of Mongolia]. Red. B. Shirendav, Sh. Natsagdorj. Ulaanbaatar: Ulsyn Khevleliyin Khereg Erkhlekh Khoroo [State Press Committee], 1966-1969.

Erdenezogt N.Mongolyn belcheeriyin mal aj akhui [Mongolian pastoral livestock]. Ulaanbaatar, 1998 on.

Jambaldorj S. Temee tengeriyin amitan [Camels are celestial beings]. Ulaanbaatar, 1997 on.

Mongol nüüdelchdiyin tayilbar toli I (ger, khuvtsas, mal aj akhui) [Dictionary of Mongolian nomads I (ger, clothes, animal husbandry)]. Ulaanbaatar: Monsudar khevleliyin gazar [Monsudar Publishing House], 2020 on.

Mongolyn ugsaatny züyin kheeriyin sudalgaany ekh khereglegdekhü̈n [Original materials for Mongolian ethnographic field research]. Bot VI. Erkhelsen S. Chuluun; khyanan nyagtalj, orshil bichsen G. Tserenkhand, U. Bulag. Ulaanbaatar: Soyombo Printing, 2011.

Tömörjav M. Belcheeriyin mongol mal [Mongolian pastoral livestock]. Ulaanbaatar, 1989 on.

Tömörjav M. Mongolyn belcheeriyin mal aj akhui (Ulamjlal, Shinechlel, Erchimjü̈̈lel) [Mongolian Pastoral Livestock (Tradition, Innovation, Intensification)]. Ed. J. Bataa. Ulaanbaatar, 2004 on.

Tserenpuntsag Sh.Temeen süreg [A herd of camels]. Ulaanbaatar, 1972 on.

Tseveenjav D. BNMAU-yn temeenii aj akhuyin ündes [Basics of camel breeding in the People's Republic of Mongolia]. Ulaanbaatar, 1990 on.

Tümenjargal D., Mendsaikhan T. Eljigen khalkhyn tü̈̈kh (guravdugaar devter) [History of Eljigen Khalkh (third book)]. Ulaanbaatar, 2017.159-163-r tal. 